\title{
THE EFFECT OF PORNOGRAPHY DISCOURSE ON THE RECEPTION OF STENCIL NOVELS BY ENNY ARROW
}

\author{
Ariska Puspita Anggraini ${ }^{1 *}$; Dwi Susanto²; Wakit Abdullah Rais ${ }^{3}$ \\ ${ }^{1,2,3}$ Graduate School of Cultural Studies, Universitas Sebelas Maret \\ J1. Ir. Sutami No. 36-A, Kentingan, Surakarta 57126, Indonesia \\ 1ariskaanggraini@gmail.com; ${ }^{2}$ dwisastra81@gmail.com; ${ }^{3}$ abdullahwakit@yahoo.com
}

Received: $08^{\text {th }}$ January 2021/ Revised: $07^{\text {th }}$ March 2021/ Accepted: $08^{\text {th }}$ March 2021

How to Cite: Anggraini, A. P., Susanto, D., \& Rais, W. A. (2021). The effect of pornography discourse on the reception of stencil novels by Enny Arrow. Humaniora, 12(2), 75-80.

https://doi.org/10.21512/humaniora.v12i2.6905

\begin{abstract}
The research aimed to analyze pornography discourse in the reception of Enny Arrow's stencil novels between two millennial men. This was a qualitative research. The research sample focused on two millennial men in Surakarta who read the stencil novels intensively. Data were obtained by interview, and observations were conducted over six months. The research observed two newly recognized millennial men to read and interpret the stencil novels. After that, the research looked at the effect on the social relationships of the participants. The theory used to analyze the data was Normand Holland's psychoanalytic literary reception. After data analysis process, it is revealed that pornography discourse makes the participants think that the stencil novels are entertaining but can be a taboo subject to discuss with others. Because of the pornography discourse, participants also think that story on the stencil novels should not be used as a general topic conversation.
\end{abstract}

Keywords: pornography discourse, reader reception, stencil novels

\section{INTRODUCTION}

The topic of pornography always has a sensational power. Mass media coverage of the circulation of erotic videos from public figures has always been viral in society. In contrast to other topics that often cause differences of opinion, reporting on pornography seems to reduce conflicts of differences in society. Talking about pornography, of course, cannot be separated from sex, which is a popular theme in modern society. The commercial value of sex is also very high, so the media compete to present sex as the most important thing than others (Gunawan, 2000). The high commercial value of sex can also be seen in the phenomenon of stencil novels.

Stencil novel is a novel with storylines or dialogues that contain erotica elements. The most famous stencil novel in Indonesia is Enny Arrow's stencil novel which was famous from 1970 until 1990 era. After the first publication in 70s, Enny Arrow's stencil novel immediately became the best-selling book. It was considered the most profitable for traders in Pasar Senen (Arifin, 2019). Gradually, Enny Arrow is changed into a brand to attract consumers. Until now, Enny Arrow's stencil novel is still in demand, even being sold at prices many times higher than the original price.

This phenomenon also proves that pornography does have an alluring side. Pornography has a high appeal because it creates both fear and curiosity (Prabasmoro, 2007). On the other hand, Muhammad (2013) has said pornography makes women are viewed from the aspect of the body, sex, and biology only, which is claimed as men's pleasure. It also places women in various areas of life, be it social, political, economic, religious, or cultural, that are marginalized under the dominance of male superiority (Nugroho, 2019).

The research uses Normand Holland's theory of reader-response criticism. The theory uses a psychoanalytic approach for getting readers' reactions and responses in interpreting a work. Based on readerresponse theory, readers give meaning to literary work as their reaction and response to the text because 
literary work will have no meaning if it does not get a response from its readers. The response is utterances of the reader or how the literary work is received according to experiences (Suarnaningsih, Junaid, \& Nahdhiyah, 2020).

Holland believes that humans react to literary texts they read in the same psychological way they carry on in everyday life (Mambrol, 2016). The interpretation of a text is a product of the reader's fear, defense, need, and desire towards the text (Tyson, 2006). In other words, the readers' interpretation of work reflects themselves, not the text they read. Holland argues that gender, age, class, or the reader's experience also influenced their interpretation of the text (Holland, 1980). The readers who have the same age, gender, class, and interpretation ability will also have similar interpretation results in interpreting a work.

The interpretation of the text also determines the reader's view of discourse. Conversely, the interpretation of a text can also influence the way readers interpret a text. It is because discourse has a close relationship with social contexts that can represent experiences. Eriyanto (2001) has argued that discourse as a language can also connect humans and objects outside of themselves. That way, human experience can be expressed through the language it uses.

The discourse formed in society can determine social conditions. It is because discourse is controlled and conditioned socially (Silaswati, 2019). On the other hand, the social context in society also determines the reception of a text. Thus, indirectly the circulation of discourse can also influence a person's reception of a text he reads.

Based on this explanation, the research will analyzes the influence of pornography discourse on the reception of readers of Enny Arrow's stencil novels between two millennial men. The research, the researchers chose two millennial men in Surakarta whom they just met to be involved in the research process for one year.

The researchers choose the participants because they have extensive knowledge about the topic in the research. They are also neutral and have no personal interests. Because of that, the research can be objective. During its period, the participants are asked to read various stencil novels by Enny Arrow, such as Sepanas Bara and Hari Kelabu. The researchers also ask about their experiences and the impact of the reading on their social relations.

The researchers are also involved in the participant's social environment for knowing the further effect of the reception on their social conditions. It is because socio-cultural conditions and personal experiences affect the interpretation of the text (Fathurizki \& Malau, 2018).

\section{METHODS}

The research applies a qualitative method. The research is conducted in Surakarta with a sample of two millennial men. Participants are voluntary, the selection is based on the following considerations: (1) The ages of 23 and 24 are millennial ages (Ester, 2016), representing modern humans' views. (2) Researchers and participants before the research began do not have a close relationship. They just know each other by social media and then try to make friends during the research. So, the result of the research can be neutral and objective. (3) The participants have extensive knowledge about the research topic. They also have consumed similar pornography content. Data analysis uses psychoanalytic literary reception analysis theory which focuses on the participants' social and psychological factors. The researchers ask the participants to read two of Enny Arrow's stencil novels intensively for data. The stencil novel is deliberately chosen as the material object because this erotic literature is still in demand. The contents of those novels have many vulgar dialogues or narrations. After that, the researcher asks the participants to interpret the stencil novel by Enny Arrow that they read.

The research also involves interviewing and observations to see further how the discourse affects Enny Arrow's stencil novels. The interview is done by asking about the social condition of the participants, such as their family condition, education, and others. For observation, researchers try to join the community or friendship environment of participants for six months. Before the reading process, participants are asked these questions, 'Have they ever consumed pornographic content?', 'What makes them interested in reading Enny Arrow's stencil novel?', and 'What do they think about pornography?'. After the reading process, the participants are also asked what title of the novels they like and the description or dialogues that impressed them.

\section{RESULTS AND DISCUSSIONS}

Before reading the novel, the researchers interview the participants to find out their backgrounds. For privacy purposes, the names of participants are disguised as Jono and Junet. Interviews are conducted separately. The interview results obtained are in Table 1.

When getting the first question, the two participants give relatively the same answer. Both Junet and Jono have access to pornographic content before getting to know Enny Arrow's stencil novels. Junet and Jono have admitted that they are interested in reading Enny Arrow's stencil novels because they are curious. Moreover, in modern times, novels that depict sex scenes vulgarly are hard to find. Access to pornography is now mostly found in digital form or video and on platforms spread on the internet. 
Table 1 Conditions of Participants

\begin{tabular}{|c|c|c|c|}
\hline No & Name & Age & Social Background \\
\hline 1 & Junet & 24 years old & $\begin{array}{l}\text { He works as writer in } \\
\text { Surakarta and likes } \\
\text { reading. He was born in } \\
\text { Central Java in } 1996 \text { and } \\
\text { raised in an environment } \\
\text { with thick Javanese culture } \\
\text { and religious values. }\end{array}$ \\
\hline 2 & Jono & 23 years old & $\begin{array}{l}\text { He works as videographer } \\
\text { in Surakarta. He prefer } \\
\text { watching film than reading } \\
\text { a book. Jono was Born in } \\
\text { Pekanbaru in } 1997 \text { and } \\
\text { raised in an environment } \\
\text { with Malay customs and } \\
\text { not too strong religious } \\
\text { values. }\end{array}$ \\
\hline
\end{tabular}

Jono and Junet also interpret pornography as merely a medium or means of entertainment. For them, the topic of pornography should not be discussed directly in social circles either. Before reading the stenciled novels, Jono interprets pornography as an entertainment medium that is addictive. They consider pornographic talk could be a humorous topic that dilutes the conversation, but there are certain limitations when talking about it in the community.

After that, the two participants are asked to read various Enny Arrow stylized novels. However, the discussion of the reader's reception in the research focuses on the titles Sepanas Bara and Hari Kelabu. Sepanas Bara tells the story of the relationship between Rini, a single parent, and her boyfriend, Budiman. The novel's main conflict is Rini, who hopes her lover will immediately provide certainty about their relationship. However, Budiman never gave certainty because he was afraid of commitment in a relationship. The novel entitled Hari Kelabu tells the story of the domestic relationship between Bahri and Nita. The conflict occurred when the character Bahri experienced impotence not to give satisfaction to his wife. Until finally, the wife decided to have an affair with her old friend. Most of the novels tell about the relationship between men and women. The conflict in each novel is full of sex scenes or erotic narratives.

Then the participants are asked to retell the essence of each of the novels. After that, the researchers ask general questions, such as, 'Did the participants like the storyline at this level?' and 'Which scenes or dialogues are memorable in each novel title they read?' It is used or analyzing the participant's way of understanding and perceptions of a literary text. The reader's way of understanding and perceptions of a literary text and the reader's experience influence the interaction between the reader and a text that contributes to the development of interpretation and reconstruction of the ideas expressed in the text (Spirovska 2019). The scenes that impressed the participants can be seen in Table 2 and 3 .
Table 2 Scenes or Dialogues that Impress Junet

\begin{tabular}{ccl}
\hline No & Title & \multicolumn{1}{c}{ Scene or dialogue } \\
\hline $1 \quad$ Sepanas Bara & $\begin{array}{l}\text { Conversation between Budiman } \\
\text { and Rini as a couple. Rini asks } \\
\text { about his commitment to their } \\
\text { relationship (page 21) } \\
\text { When Bahri (the first man } \\
\text { character) says to his wife Nita, } \\
\text { he found medicine to arouse his } \\
\text { manhood (page 55-57) }\end{array}$ \\
\hline
\end{tabular}

Table 3 Scenes or Dialogues that Impress Jono

\begin{tabular}{ccc}
\hline No & Title & \multicolumn{1}{c}{ Scene or dialogue } \\
\hline 1 & Sepanas Bara & $\begin{array}{l}\text { The scene of a child helping his } \\
\text { mother to have sex with his lover } \\
\text { (page.14). }\end{array}$ \\
2 & Hari Kelabu & "Mama had an affair" (page 63). \\
\hline
\end{tabular}

After reading the novel, Junet prefers Enny Arrow's stencil novels to adult content on the internet. He can enjoy the dialogues or adult scenes in the novel because of its storyline. He thinks the adult content on the internet, especially in video form, is grossly vulgar and disgusting. It can happen because of his reading hobby, which helps Junet has a pleasant experience while reading the novel.

Junet is also more open when discussing the storyline and telling his interpretation of the stencil novels. He can even show sympathy for the female character in the novel. He argues that Enny Arrow's stenciled novels contains elements of sexism, in which female characters are always described as those who must be able to provide satisfaction to men.

The scenes or dialogues in the novel that impress Junet mostly show the closeness between the couple. According to Junet, the scene or dialogue depicts the feelings or emotional sides that are interwoven between the characters. When interviewed, he said:

\footnotetext{
"Basically, I only value something personal. In the context of relationships between men and women, intimate relationships are not usually described in a vulgar way. However, in the context of the novel, I consider it part of the course of the story. For me, the context in that relationship is sincerity and mutual love, not just satisfaction."
}

When analyzed with the theory of psychoanalytic literary reception from Holland, the environment of friendship and family also influences Junet's response. When reading parts of memorable scenes or dialogues (see Table 2), Junet relates this to his experience when he received a boarding school education and his family where things related to pornography or sex are taboo to discuss. In Holland's theory, what is experienced by Junet is a process of 'defense mechanism', namely, 
the process of text raises psychological defenses in the reading diary (Tyson, 2006). The narrative that is too vulgar in the novel makes Junet experience inner contradictions within him. However, he successfully adapts through dialogue or scenes that show conversations that involve feelings or emotions between characters.

After reading the novel, Junet interprets pornography as a medium of entertainment that is enjoyed personally, not to be discussed in the public domain. Here is Junet's statement:

"When I read the novel, I felt that pornography was synonymous with sex. Many dialogues or narratives in the stencil novels depict male or male intimate parts and sexual scenes written in vulgarity. If we talk about it (intimate parts and sexual scenes) in the public domain, we can be considered impolite. So, things about pornography that should be personal should not be discussed in the public domain."

Based on his social background, Junet is a native Javanese man who grew up in an environment that adheres to Javanese customs. Apart from that, Junet also lived in a pesantren during his junior high school education. Junet's statement illustrates his social background. In eastern culture, especially Javanese, talking about sex or pornography is considered taboo. It is because some Javanese parents still have feelings of reluctance and narrow views prevent sexual disclosure at home, especially for parents who are not outspoken and highly uphold Eastern ethics (Suwardi, 2009). Therefore, as a man who grew up in the Java Junet community, he feels the same way. However, the storyline in the novel allows Junet to enjoy pornographic scenes or narratives in the novel. This condition shows the occurrence of a fantasy process in Junet. After discovering the adaptation process in reading, he gets a fantasy that makes him happy (Holland, 1980).

Junet's reception of the discourse on pornography in the novel also indirectly shows his view as a modern man about sex. Sex also contains a social construction, so that although current sexuality is a relatively free mode of expression, it is still connected to the conditions surrounding it. Among modern humans, sex is also accompanied by feelings, namely love, which is part of human beings' nobility (Gunawan, 2000).

From the reception, it can be seen that the opinion of pornography as unifying the nation does not affect the reality of Junet. According to Junet, the opinion of pornography as a nation that unites many people in mass media or social media is just a joke and hyperbole. For him, pornography should be a personal consumption, not a general topic of conversation. This is evident from the statement as follows:

"I prefer to enjoy pornographic content from Enny Arrow's stenciled novels because there are stories and sex scenes that are written although vulgar but still have a personal element. However, pornographic content on the internet, especially in video form, is too vulgar and does not show an emotional side."

For Jono, the sex scene between an adult man and woman who is assisted by a small child is the thing that impresses him when he reads Sepanas Bara. While the memorable scene when reading Hari Kelabu is a dialogue scene where a wife confesses that she has had an affair (see Table 3).

Unlike Junet, Jono dislikes Enny Arrow's stencil novel. Jono prefers to access pornographic content from the internet, which is mostly packaged in videos because it makes him more sexually desirable than when reading stenciled novels. It could be because Jono prefers watching films or videos to reading a book. Following is Jono's statement:

"I would rather watch porn than read a stencil novel. Direct porn videos show scenes that arouse libido, but reading the stencils made me think first because of its storyline."

In reading a literary work, readers bring expectations that reflect their personal experiences. Most likely, Jono does not like Enny Arrow's stencil novel because he feels he is not connected to the existing storyline. The expectations he brings based on his personal experience do not materialize in the novel. When viewed from his social background, Jono is classified as a person who is less open to the opposite sex. He spends more of his time socializing with other men. This background likely makes him less connected to the storyline in the novel Enny Arrow, which mostly tells the relationship between men and women.

This could also reflect the existence of a 'defense mechanism' process. According to Holland (1980), in this process, individuals find things they do not like and then try to avoid them by implementing adaptive strategies. Jono's adaptive strategy can be seen when he finds a scene or dialogue that impresses him (see Table 3). 'Defense mechanism' also depends on the theme of individual identity. According to Jono, the scene impressed him because it seems unreal or too contrived. Following is Jono's statement:

"The scene is too far-fetched. It is impossible in the real world for a child to see and help the intimate relationship between the mother and boyfriend of her mother."

When reading the narrative that tells the scene, Jono internalizes it with his personal experience. In Jono's case, he experiences repression, where he unconsciously feels a sense of fear when he sees the scene. He buries this fear by rejecting the storyline in the novel. He does this because he refuses to see something not be pleasant to see. That is why he thinks 
that the scenes never happen in reality. It is called a defense mechanism that makes the egos' readers refuse to accept what it cannot tolerate (Alatriste, 2013). Jono's defense mechanism is represented in the form of repression. It is done to suppress unconscious anxiety when remembering emotional experiences that have been in the past (Minderop, 2010).

While reading the novel entitled Hari Kelabu, Jono feels that the scene that impresses him (see Table 3) reminded him of his childhood experience. Following is Jono's statement:

"While reading Hari Kelabu, I suddenly remember a childhood incident, well, there was a similar conflict in the family. Unfortunately, the scene of confession from his wife looks exaggerated. It feels like nothing in the real world for someone who cheats right away admits her mistake."

Jono finds connections with the characters in the story so he can enter into them. If analyzed with Holland's theory, this can be interpreted as the liberation of individual fantasies. According to Holland (1980), this process is a form of individual absorption of the reality that appears in the text. Alatriste (2013) has realized that literary contexts have the potential to bring out a reader's fantasies and secret wishes precisely because such reading frameworks can make those fantasies and wishes more socially acceptable.

After reading the two novel titles, Jono interprets pornography as an addictive entertainment medium. However, he thinks pornography is only for personal consumption. So, he enjoys pornography while alone. Jono also feels that pornography should not be a topic of public discussion. On the other hand, things that smell pornography can also be a discussion that dissolves the inner circle atmosphere, but with certain limitations. This statement also reflects Jono's repression when interpreting pornography. Unconsciously, pornography has created fear as well as created curiosity and fulfillment as a man. Holland has also said that individual interpretations of a text could also be produced from fear, defense, and need (Tyson, 2006). The opinion of pornography as unifying the nation also does not seem to affect Jono's reality. He interprets pornography as a medium of entertainment that is only allowed for personal consumption, not for general topics of conversation. For him, there must still be certain limitations when discussing pornography with other people. Jono's way of interpreting pornography also shows the views of modern humans. Technological sophistication that facilitates access to technology has reduced the meaning of sex as a consumption material only (Gunawan, 2000).

The observations are carried out for six months by engaging directly in the participants' social lives. From the observation, the researchers have found that pornography in the participants' social life can become a topic of conversation that can break the situation in the community, especially among men. They often use pornographic topics as jokes. However, the words or sentences used when discussing pornography still have limitations or are not spoken in a vulgar manner.

When the researchers and participants discuss Enny Arrow's stenciled novel's contents, the sentences or words used by the participants are also limited. It is as if the participants do not want to speak the erotic scenes or dialogues in the novels openly. This condition occurs because of the participants' social background and culture, who consider pornography is taboo and negative. Participants also often laugh when telling scenes in the stenciled novels. When discussing, they think the storylines in the novels are funny.

From the observations, it appears that the participants experienced psychological conflicts within themselves. Extensive access to information and technology has turned pornography into a massive consumption practice. As modern humans, they also view pornography as a consumption medium to satisfy libido. However, their social environment, which considers pornography taboo, limits participants from discussing pornography in public. Thus, the participants use deliberately restricted language when retelling erotic scenes or dialogue. It shows a relationship between the text and the reader's self, which helps create meaning exploration. Exploring meaning also requires inter textualization and the association of readers with their own life experiences to interpret the text (Iskhak et al., 2017).

\section{CONCLUSIONS}

From the research results conducted by interviews and observations, researchers have found that the participants interpret pornography as consumption and taboo. Therefore, pornographic content can only be enjoyed privately, not as a general topic of conversation. This meaning is formed because of the culture of the participants who perceive pornography as taboo. However, psychological factors as an adult make them attracted to accessing pornographic content. This condition also shows the existence of a 'defense mechanism' in which the text creates contradictions within the individual.

However, the reception of Enny Arrow's stenciled novels for each reader also has several differences because their backgrounds are also different. Junet has experience of reading fun novels so that he can enjoy the storyline in the novel. It can happen because he has a hobby of reading and a background as a writer. Junet also likes scenes that show the closeness between men and women because he also has extensive social relations with the opposite sex. Junet considers pornography to be more than just a show containing sex scenes. According to Junet, pornographic content also requires a storyline to be enjoyed and does not cause disgust.

On the other hand, Jono prefers to access pornographic content packaged in the form of videos. 
For Jono, the storyline in Enny Arrow's stencil novels is too wordy, so that his sexual desire is higher when watching pornographic videos. Therefore, Jono cannot have a pleasant reading experience. It can happen because Jono is a visual type that focuses more on vision and does not like reading activities. Jono considers pornography as content that only shows sex scenes in order to generate libido. It is why he does not like Enny Arrow's stencil novels. Unlike Junet, the scenes that impress Jono remind him of childhood events and the knowledge he has acquired. This difference in reception occurs because of differences in background, age, education, and reading experience. The researchers hope that future research can explore more detail how the effect of pornography on the reader reception and find the ideology which constructs that discourse.

\section{REFERENCES}

Alatriste, L. (2013). Psychoanalytic literary criticism: Using Holland's DEFT model as a reader response tool in the language classroom. Language and Psychoanalysis, 2(1), 20-49. https://doi.org/10.7565/ landp.2013.0002.

Arifin, E. (2019). Siapakah Enny Arrow? Retrieved $1^{\text {st }}$ January 2021 from https://serikatnews.com/ siapakah-enny-arrow/.

Eriyanto. (2001). Analisis wacana. Yogyakarta: LkiS.

Ester. (2016). Mengenal generasi milenial. Retrieved $5^{\text {th }}$ March 2021 from https://www.kominfo. go.id/content/detail/8566/mengenal-generasimillennial/0/sorotan_media.

Fathurizki, A., \& Malau, R. (2018). Pornografi dalam film: Analisis resepsi film "Men, Women \& Children". Jurnal Kajian Televisi dan Film, 2(1), 19-35. https:// doi.org/10.24198/ptvf.v2i1.1134.

Gunawan, F. X. (2000). Refleksi atas kelamin. Magelang: Indonesia Tera.
Holland, N. N. (1980). Unity, identity, text, self. In J. Tompkins (Ed.), Reader response criticism (pp. 118134). Baltimore: Johns Hopkins UP.

Iskhak., Saleh, M., Sofwan, A., \& Hartono, R. (2017). Investigating the effects of reader response journals on the quality of teacher trainees' responses to literary works. Theory and Practice in Language Studies, 7(10), 831-840. http://dx.doi.org/10.17507/ tpls.0710.02.

Mambrol, N. (2016). Psychological reader response theory. Retrieved from https://literariness.org/2016/11/18/ psychological-reader\%E2\%80\%91 responsetheory/.

Minderop, A. (2010). Psikologi sastra. Yogyakarta: Yayasan Pustaka Obor Indonesia.

Muhammad, H. (2013). Bukan soal tubuh, tetapi ruh. Jurnal Perempuan, 18(2), 103-113.

Nugroho, B. A. (2019). Perlawanan perempuan terhadap dominasi patriarki dalam novel 'Geni Jora' karya Abidah El Khalieqy kajian feminisme psikoanalisis Karen Horney. Jurnal Sastra Indonesia, 8(2), 148156.

Prabasmoro, A. P. (2007). Kajian budaya feminis: Tubuh, sastra, dan budaya pop. Yogyakarta: Jalasutra.

Silaswati, D. (2019). Analisis wacana kritis dalam pengkajian wacana. Metamorfosis: Jurnal Bahasa, Sastra, dan Pengajarannya, 12(1), 1-10.

Suarnaningsih, R., Junaid, S., \& Nahdhiyah. (2020). Audience response of racism in 'Hidden Figures' movie. Elite Journal, 7(1), 89-101. https://doi. org/10.24252/elite.v7i1a8.

Suwardi. (2009). Kramanisasi seks dalam kehidupan orang Jawa melalui ungkapan tradisional. Humaniora, 21(3), 274-284. https://doi.org/10.22146/jh.971.

Spirovska, E. (2019). Reader-response theory and approach: Application, values and significance for students in literature courses. SEEU Review, 14(1), 20-35. https://doi.org/10.2478/seeur-2019-0003.

Tyson, L. (2006). Critical theory today. New York: Routledge. 